\title{
Information for Contributors
}

The JOURNAL OF THE AMERICAN OSTEOPATHIC ASSOCIATION is the scholarly publication of the osteopathic medical profession. It provides a forum for communicating and disseminating philosophical concepts, clinical practice observations, and scientific information, and for defining the current status of the profession. It is directed toward the osteopathic primary care physician with a broad range of interests and provides a clinical and scientific update for the osteopathic specialist.

JAOA is the official scientific publication of the American Osteopathic Association. Articles are accepted with the understanding that they have not been published elsewhere and that they are not simultaneously under consideration by any other publication. Priority in publication is given to original work. Where appropriate, an osteopathic medical slant is expected.

JAOA publishes original investigations, current reviews with an expert critical viewpoint, and didactic discourses in a wide variety of clinical fields.

JAOA welcomes submission of papers in the following categories:

\section{Original Contributions}

Documentation of original clinical or applied research. Basic science research will be accepted only in abstract form unless the work is specifically related to clinical application. Length of the paper is optional but references are limited to 30 .

\section{Brief Reports}

Substantive, but brief, documentation of clinical information, pilot investigation, theoretical concepts, clinical "pearls," etc. Length limited to 750 words, a maximum of 10 references, and 1 or 2 figures.

\section{Case Reports}

Unusual clinical presentations with newly recognized or rarely reported features. Length is limited to 1500 words, 4 illustrations, and 10 references.

\section{Clinical Practice}

Articles that have practical application for both general practitioners and specialists and present an expert critical viewpoint. Length is limited to 1500 words, 2 illustrations, and 10 references.

\section{Medical Education}

Articles on undergraduate and graduate osteopathic medical education. Length is optional. Illustrative tables and graphs are welcomed.

\section{Special Communications}

Informed commentary and hypotheses on medical scientific topics, including controversial issues: Text length, 1500 to 2000 words. Appropriate illustrations will be considered.

\section{Letters to the Editor}

Comment on articles published in the JAOA or new information on clinical topics. Length is limited to 500 words with a maximum of 5 references and 2 illustrations.
Contributions are accepted from members of the American Osteopathic Association, faculty members in osteopathic medical colleges, and, in unusual circumstances, from others, such as guest lecturers at osteopathic medical meetings.

In all but rare instances, trainee papers must include the trainer as an author. The coauthorship implies review and additional material from the experience of the senior physician.

\section{Submission}

Submit all papers to Thomas Wesley Allen, DO, Editor in Chief, JAOA, American Osteopathic Association, 142 E Ontario St, Chicago, IL 60611-2864.

\section{Editorial review}

All papers received for JAOA consideration are submitted to referees in the field(s) of interest represented by the paper. Notification of acceptance or rejection usually is given within three months after acknowledgment of the paper; publication follows as soon as possible thereafter, depending on the current backlog of papers.

Because of the large number of manuscripts considered by JAOA, some are necessarily rejected through no fault in the paper, but because of duplication of subject matter, a preference for original material over some forms of review, or the necessity to establish priorities on the use of limited space.

\section{Checklist of submission requirements}

- Manuscript

1. Type all text, references, and tabular material caps and lower cases double-spaced with 1-inch margins all around. (No script type face. Do not use daisy wheel typewriter or printer.) Number all pages consecutively. 2 . Submit original plus 4 photocopies. Be sure to retain one copy for your files.

3. Check that all references, tables, and figures are cited in the text and in numerical order.

4. Include a cover letter that gives the author's full name and address, telephone number, institution from which work initiated, and academic title or position.

- Illustrations

1. Submit at least 3 sets of illustrations and clearly label each.

2. Photos should be submitted as $5 \times 7$ glossy black and white prints with high contrast. On the back of each, clearly indicate the top of the photo. Use a photocopy to indicate the placement of arrows and other markers on the photos. If color is necessary, submit clearly labeled $35-\mathrm{mm}$ slides with the tops marked on the frames. All illustrations will be returned to the authors of published manuscripts. 
"I was devastated when I found out I had genital herpes. What a relief when my doctor recommended a treatment program including Zovirax Ointment."

Zovirax ${ }^{\circledR}$ (acyclovir) Ointment 5\% is an ideal complement to any treatment program for initial herpes genitalis. As clinical studies confirm, Zovirax Ointment $5 \%$ significantly lessens the duration of pain, shortens viral shedding, and speeds healing. ${ }^{1-3}$

Whenever the comfort of a topical antiviral medication is desired, prescribe Zovirax Ointment 5\% for initial herpes genitalis. It suits her needs-just when she needs it most.

In initial herpes genitalis,

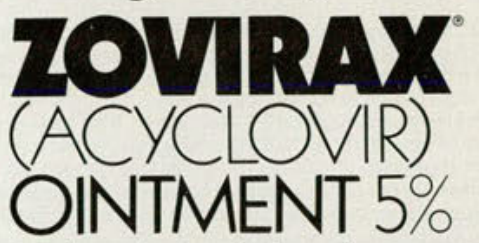
Antiviral Action... Proven Results

Please see brief summary of prescribing information on next page.

References: 1. Lacey CJN, Meaden JD, Darville JM, et al. Topical acyclovir ointment in the treatment of genital herpes simplex virus. infections. Eur / Sex Trans Dis. 1985;2:167-170. 2. Thin RN, Nabarro JM, Parker JD, Fiddian AP. Topical acyclovir in the treatment of initial genital herpes. Br / Vener Dis, 1983;59:116-119. 3. Corey L, Benedetti jK, Critchlow CW, et al. Double-blind controlled trial of topical acyclovir in genital herpes simplex virus infections. Acyclovir symposium. Am / Med. 1982;73:326-334. 


\section{Information for contributors}

Before prescribing, please consult full package insert, a summary of which follows: INDICATIONS AND USAGE: Zovirax (ACyclovir) Ointment $5 \%$ is indicated in the management of initial herpes genitalis and in limited nonlife-threatening mucocutaneous Herpes simplex virus infections in immunocompromised patients. In clinical trials of initial herpes genitalis, Zovirax Ointment $5 \%$ has shown a decrease in healing time and in some cases a decrease in duration of viral shedding and duration of pain. In studies in immunocompromised patients with mainly herpes labialis, there was a decrease in duration of viral shedding and a slight decrease in duration of pain.

By contrast, in studies of recurrent herpes genitalis and of herpes labialis in nonimmunocompromised patients, there was noevidence of clinical benefit; there was some decrease in duration of vira shedding.

Diagnosis: Whereas cutaneous lesions associated with Herpes simplex infections are often characteristic, the finding of multinucleated giant cells in smears prepared from lesion exudate or scrapings may assist in the diagnosis.' Positive cultures for Herpes simplex virus offer a reliable means for confirmation of the diagnosis. In genital herpes, appropriate examinations should be performed tor confirmation of the diagnosis. In genital herpes.

CONTRAINDICATIONS: Zovirax Ointment $5 \%$ is contraindicated for patients who develop hypersen sitivity or chemical intolerance to the components of the formulation.

WARNINGS: Zovirax Ointment $5 \%$ is intended for cutaneous use only and should not be used in the eye. PRECAUTIONS:

General: The recommended dosage, frequency of applications, and length of treatment should not be exceeded (see DOSAGE AND ADMINISTRATION). There exist no data which demonstrate that the use of Zovirax Ointment $5 \%$ will either prevent transmission of infection to other persons or prevent recurrent infections when applied in the absence of signs and symptoms. $70 v i r a x$ Ointment $5 \%$ should not be used for the prevention of recurrent HSV infections. Although clinically significant viral resiswith the use of Zovirax Ointment $5 \%$ has not been observed this possibility exists. Drug Interactions: Clinical experience has identified no interactions resulting from topical or systemic administration of other drugs concomitantly with Zovirax Ointment $5 \%$.

Carcinogenesis, Mutagenesis, Impairment of Fertility: Acyclovir was tested in lifetime bioassays in rats and mice at single daily doses of 50,150 and $450 \mathrm{mg} / \mathrm{kg} /$ day given by gavage. These studies showed no statistically significant difference in the incidence of benign and malignant tumors produced in drug-treated as compared to control animals, nor did acyclovir induce the occurrence of tumors earlier in drug-treated animals as compared to controls. In 2 in vitro cell transtormation assays, used toprovide preliminaryasessment of potential oncogenicity in udvance of these mo defintivelletime bioavide bioassas in red used in one system and the resuling morphologically transtormed cells formed tumors when inoculated into immunosuppressed, syngeneic, weanling mice. Acyclovir was negative in another transformation system.

No chromosome damage was observed at maximum tolerated parenteral doses of $100 \mathrm{mg} / \mathrm{kg}$ acyclovir in rats or Chinese hamsters; higher doses of 500 and $1000 \mathrm{mg} / \mathrm{kg}$ were clastogenic in Chinese hamsters. In addition, no activity was found in a dominant lethal study in mice. In 9 of 11 microbia and mammalian cell assays, no evidence of mutagenicity was observed. In 2 mammalian cell assays (human lymphocytes and L $5178 \mathrm{Y}$ mouselymphoma cells in vitro) positive response for mutagenicity and hromosomal amageccurred, but tonly at concentrations atleast 1000 times the plasmalevels

Acyclovir does not impair fertility or reproduction in mice at oral doses up to $450 \mathrm{mg} / \mathrm{kg} /$ day or in rats at subcutaneous doses up to $25 \mathrm{mg} / \mathrm{kg} /$ day. In rabbits given a high dose of acyclovir (50 $\mathrm{mg} / \mathrm{kg} /$ day, s.c.), there was a statistically significant decrease in implantation efficiency.

Pregnancy: Teratogenic Elfects. Pregnancy Category C. Acyclovir was not teratogenic in the mouse $(450 \mathrm{mg} / \mathrm{kg} /$ day, p.o.), rabbit ( $50 \mathrm{mg} / \mathrm{kg} /$ day, s.C. and i.v.) or in standard tests in the rat ( 50 $\mathrm{mg} / \mathrm{kg} / \mathrm{day}$, s.c.). In a non-standard test in rats, fetal abnormalities, such as head and tail anomalies, were observed following subculaneous administration of acyclovir at very high doses associated with quate and well-controlled studies in pregnant women. Acyclovir should not be used during pregnan cy unless the potential benefit justifies the potential risk to the fetus.

Nursing Mothers: It is not known whether this drug is excreted in human milk. Because many drugs are excreted in human milk, caution should be exercised when Zovirax is administered to a nursing woman.

ADVERSE REACTIONS: Because ulcerated genital lesions are characteristically tender and sensitive to any contact or manipulation, patients may experience discomfort upon application of ointment. In the controlled clinical trials, mild pain (including transient burning and stinging) was reported by $103(28.3 \%)$ of 364 patients treated with acyclovir and by $115(31.1 \%)$ of 370 patients treated with placebo; treatment was discontinued in 2 of these patients. Other local reactions among acyclovirtreated patients included pruritus in $15(4.1 \%)$, rash in $1(0.3 \%)$ and vulvitis in $1(0.3 \%)$. Among the placebo-treated patients, pruritus was reported by $17(4.6 \%)$ and rash by $1(0.3 \%)$. In all studies, there was no significant difference between the drug and placebo group in the rate or type of reported adverse reactions nor were there any differences in abnormal clinical laboratory findings. OVERDOSAGE: Overdosage by topical application of Zovirax Ointment $5 \%$ is unlikely because of limited transcutaneous absorption (see Clinical Pharmacology)

DOSAGE AND ADMINISTRATION: Apply sufficient quantity to adequately cover all lesions every 3 hours 6 times per day for 7 days. The dose size per application will vary depending upon the total lesion are lesion A a buts conld aprox area. A finger cot or fubber glove should be used when applying Zovirax to prevent autoinoculation of other body sites and transmission of infection to other persons. Therapy should be initiated as early as possible following onset of signs and symptoms.

HOW SUPPLIED: Zovirax Ointment $5 \%$ is supplied in $15 \mathrm{~g}$ tubes (NDC 0081-0993-94) and $3 \mathrm{~g}$ tubes (NDC 0081-0993-41). Each gram contains $50 \mathrm{mg}$ acyclovir in a polyethylene glycol base. Store at $15^{\circ}-25^{\circ} \mathrm{C}\left(59^{\circ}-77^{\circ} \mathrm{F}\right)$ in a dry place.

REFERENCES

1. Naib ZM et al. Cancer Res 33:1452-1463, 1973

2. Stahlmann R, Klug S, Lewandowski C, et al. Infection: 15(4): 261-262, 1987.

U.S. Patent No. 4199574

IMPROVING LIVES THROUGH ANTIVIRAL RESEARCH

Burroughs Wellcome Co. Research Triangle Park North Carolina 27709
3. Include a caption for each figure. For photomicrographs, indicate the original magnification and staining methods used.

4. Drawings and charts should be professionally drawn with India ink on poster board or heavy white paper. You may submit good quality photos of art rather than the originals.

\section{- Permissions}

Obtain written permission from the publisher and author to use previously published illustrations, and submit these letters with the manuscript. You also must obtain written permission from patients to use their photos if there is a possibility that they might be identified. In the case of children, permission must be obtained from a parent or guardian.

\section{- Abstract}

Provide a 150-word abstract that summarizes the main points of the paper and its conclusions.

\section{- References}

1. References are required for all material derived from the work of others. Cite all references in numerical order in the text. If there are references used as general source material, but from which no specific information was taken, list them in alphabetical order following the numbered references.

2. For journals, include the names of all authors, complete title of the article, name of the journal, volume number, date, and inclusive page numbers. For books, include the name(s) of the editor(s), name and location of publisher, and year of publication. Give page numbers for exact quotations.

- Editorial processing and reprints

All accepted articles are subject to copy editing. For Original Contributions and Brief Reports, authors must provide photocopies of all references so that statements cited in the text may be verified. Authors receive a typescript (or galley proofs) and proofs of the illustrations for approval before publication. Authors are responsible for all statements, including changes made by the manuscript editor.

Twenty-five tear sheets are provided free to each author and coauthor. Information for ordering reprints is supplied on request. Three copies of the JAOA containing the author's article will be sent on request. Papers will be entered automatically for CME credit where appropriate.

No material may be reprinted from JAOA without the written permission of the editor and the author(s). 